\title{
Signalling by Transforming Growth Factor Beta Isoforms in Wound Healing and Tissue Regeneration
}

\author{
Richard W.D. Gilbert ${ }^{1}$, Matthew K. Vickaryous ${ }^{2, *}$ and Alicia M. Viloria-Petit ${ }^{2, *}$ \\ 1 School of Medicine, University College Cork, Cork, Ireland; Richard.wd.gilbert@gmail.com \\ 2 Department of Biomedical Sciences, Ontario Veterinary College, University of Guelph, Guelph, \\ ON N1G 2W1, Canada \\ * Correspondence: mvickary@uoguelph.ca (M.K.V.); aviloria@uoguelph.ca (A.M.V.-P.); \\ Tel.: +1-519-824-4120 (ext. 53871, M.K.V.); +1-519-824-4120 (ext. 54925, A.M.V.-P.)
}

Academic Editors: Robin Muise-Helmericks and Simon J. Conway

Received: 13 May 2016; Accepted: 17 June 2016; Published: 22 June 2016

\begin{abstract}
Transforming growth factor beta (TGF $\beta$ ) signalling is essential for wound healing, including both non-specific scar formation and tissue-specific regeneration. Specific TGF $\beta$ isoforms and downstream mediators of canonical and non-canonical signalling play different roles in each of these processes. Here we review the role of TGF $\beta$ signalling during tissue repair, with a particular focus on the prototypic isoforms TGF $\beta 1$, TGF $\beta 2$, and TGF $\beta 3$. We begin by introducing TGF $\beta$ signalling and then discuss the role of these growth factors and their key downstream signalling mediators in determining the balance between scar formation and tissue regeneration. Next we discuss examples of the pleiotropic roles of TGF $\beta$ ligands during cutaneous wound healing and blastema-mediated regeneration, and how inhibition of the canonical signalling pathway (using small molecule inhibitors) blocks regeneration. Finally, we review various TGF $\beta$-targeting therapeutic strategies that hold promise for enhancing tissue repair.
\end{abstract}

Keywords: transforming growth factor beta; TGF $\beta$; isoforms; tissue regeneration; wound healing

\section{Transforming Growth Factor Beta (TGF $\beta$ ) Signalling}

The TGF $\beta$ superfamily consists of 33 members, most of which are dimeric, secreted polypeptides. In addition to the three prototypic TGF $\beta$ isoforms (TGF $\beta 1$, TGF $\beta 2$ and TGF $\beta 3$ ), the superfamily

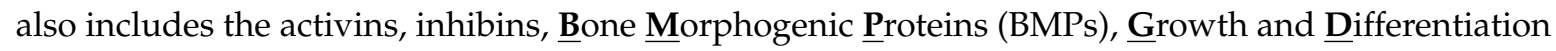

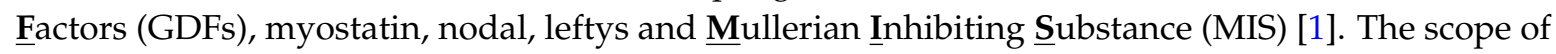
this review will be largely limited to the three isoforms of TGF $\beta$ ligand: TGF $\beta 1$, TGF $\beta 2$ and TGF $\beta 3$. The specific roles of other members of this superfamily in tissue repair and regeneration have been thoroughly reviewed elsewhere (see [2] and [3] for activins and BMPs, respectively).

Members of the TGF $\beta$ family are widely recognized as key signal transducers among multicellular animals (metazoans), including both invertebrates (e.g., the placozoan Trichoplax adhaerens [4], and acorn worms [5]), and vertebrates. The three prototypic TGF $\beta$ isoforms, TGF $\beta 1$, TGF $\beta 2$ and TGF $\beta 3$, are structurally similar cytokines encoded by separate genes that act in autocrine and paracrine manners to regulate early embryonic development, the maintenance and regeneration of adult tissues, as well as various disease processes [6-8]. TGF $\beta$ ligands are secreted as inactive precursors bound to latency-associated peptides and are either directly activated or embedded in the extracellular matrix (ECM) to be activated at a later time. In most tissues, significant amounts of TGF $\beta$ are stored in the ECM [9]. TGF $\beta$ ligand activation is accomplished by the lytic action of proteases including

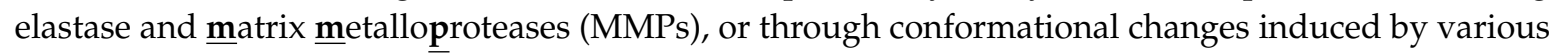
integrins $[10,11]$. 
Following release, TGF $\beta$ ligands evoke their cellular effects on target cells by binding to transmembrane dual specificity receptors, which possess strong serine/threonine kinase activity and weak tyrosine kinase activity [12,13]. TGF $\beta$ receptors are the sole cell surface serine/threonine kinase receptors known in humans [14], and can be divided into three classes: type I (T $\beta R I$; also known as activin-like kinase, T $\beta R I / A L K)$, type II (T $\beta R I I)$, and type III (T $\beta R I I I)$. To activate cellular signalling, the ligand first binds to a dimer of constitutively active T $\beta$ RII, which is then brought into close proximity with a dimer of T $\beta R I$ (ALK5 in the majority of cell types; ALK5 or ALK1 in endothelial cells [15]), allowing T $\beta$ RII to phosphorylate T $\beta R I[12,16]$. Once activated, the tetrameric receptor complex initiates an intracellular cascade that evokes the activation of canonical and non-canonical signalling pathways. Type III receptors, including the co-receptors endoglin and betaglycan, mediate the binding of specific TGF $\beta$ isoforms and further regulate receptor activity [6].

Endoglin binds to T $\beta$ RII-associated TGF $\beta$, but not to free TGF $\beta$, and is best known from its role in angiogenesis $[1,17]$. Endoglin expression by endothelial cells enhances TGF $\beta$ signalling via ALK1-Smad1 and inhibits signalling via ALK5-Smad3. However, it is important to note that endoglin function is multifaceted: it exists in two different splice variants that have opposing functions, and it can serve as a co-receptor for other TGF $\beta$ family ligands, including BMP9 and BMP10 [18]. In addition to its role in angiogenesis, emerging data indicates that endoglin is also involved (in a context-dependent manner) in fibrosis and scleroderma [18]. Similar to endoglin, betaglycan is a T $\beta$ RIII with multiple functions. These include ligand presentation to the type II receptor, and enhancement or inhibition of the action of ligands in a context-dependent manner (reviewed in [19])

Canonical TGF $\beta$ signalling pathway is mediated through cytoplasmic proteins known as

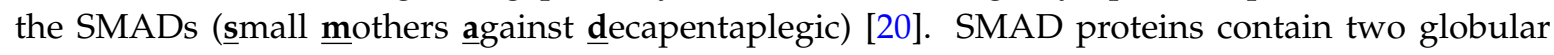
domains, termed MH1 and MH2, connected by a linker domain. The MH1 domain contains a DNA-binding domain, while the MH2 domain contains a series of hydrophobic patches that facilitate protein-protein interactions [20]. In vertebrates, there are eight members of the SMAD family, SMADs 1-8. SMADs are categorized into three classes depending on their structure and function. Receptor activated or R-SMADs (SMADs 1-3,5,8) interact with activated T $\beta R I$, resulting in their C-terminal phosphorylation $[20,21]$. In most cases, TGF $\beta$ 's (as well as activin, myostatin and nodal ligands) activation of T $\beta R I$ results in the C-terminal phosphorylation of SMAD2 and SMAD3, whereas BMPs and GDFs cause the C-terminal phosphorylation of SMAD1, SMAD5 and SMAD8 [20,21]. Similarly, TGF $\beta$-dependent activation of ALK1 on endothelial cells, which primarily occurs in response to low ligand concentration, also results in activation of SMAD1/5 [15].

An important mediator of SMAD2/3 activation is the adaptor protein known as $\underline{\mathbf{S}}$ mad anchor for receptor activation (SARA) [22]. SARA interacts with both the plasma membrane and SMAD2/3 (the latter via SMAD's MH2 domain); this ensures SMAD's proximity to the plasma membrane and the T $\beta R$ complex, thus facilitating activation of SMAD [22]. SARA's key role in TGF $\beta$ signalling is not limited to SMAD activation; SARA may also modulate the outcome and duration of the signal by regulating the balance between SMAD2 and SMAD3 and facilitating SMAD7-mediated T $\beta R I$ dephoshorylation [23]. However, the extent of SARA's involvement in TGF $\beta$ signalling might be cell-type dependent, as it was recently observed that in Hela and B-cell lymphoma cells, SARA levels do not necessarily correlate with SMAD activation, nuclear translocation and SMAD-dependent gene expression [24].

Upon C-terminal phosphorylation the common-mediator SMAD, (SMAD4) interacts with activated R-SMAD complexes to assist with their nuclear translocation. The nuclear-cytoplasmic shuttling of SMAD proteins plays a substantial role in modulating TGF $\beta$ signalling, and is determined by different mechanisms for individual SMADs. Numerous proteins have been demonstrated to play essential roles in this shuttling, including components of the nuclear pore complex, importins, exportins, and mediators of the Hippo signalling pathway [12,25].

Following nuclear translocation, activated SMAD transcriptional complexes bind to target DNA sequences to activate or repress gene expression. The recognition of specific DNA sequences and their ability to activate or repress gene expression is determined by the isoform of SMAD that is present, 
as well as numerous protein-protein interactions with transcriptional co-activators and co-repressors mediated through SMAD's MH2 domain [4]. This ability of SMAD proteins to interact with numerous other proteins allows them to act as an integration hub for cell signalling crosstalk and greatly influences signalling outcome [4].

The extent of SMAD signalling activation is modulated by different mechanisms, including competitive receptor binding by R-SMADs and I-SMADs, the specific and timely degradation of signalling mediators, and receptor trafficking. I-SMADs (SMADs 6 and 7) bind directly to the T $\beta R$ complex and block R-SMAD access to the receptor [26]. I-SMADs also compete with R-SMADs in the nucleus. Via its MSH2 domain, SMAD7 binds directly to DNA and prevents SMAD2, 3 and 4 from binding [1]. Ubiquitin-dependent proteasomal degradation of TGF $\beta$-activated R-SMADs (such as SMADs 1, 2 and 3) is mediated by different E3-type ubiquitin ligases, and modulates both their steady-state levels, as well as the duration of their activated state. Among these, the best-documented are the $\underline{\mathbf{S}}$ mad $\underline{\mathbf{u}}$ biquitination related factors 1 and 2 (Smurf1 and 2, respectively) [26]. SMAD4 is also targeted for proteasome-dependent degradation by a Smurf-independent pathway that might involve the SCFSkp2 complex [27]. Finally, I-SMADs also serve as adaptors that recruit the E3 ubiquitin ligases Smurf 1 and 2 to the T $\beta R$ complex, facilitating proteasome-dependent degradation of activated T $\beta R I$ [26]. SMAD7 can additionally recruit the phosphatase GADD34-PP1c to the activated T $\beta R$ complex to attenuate signalling [1].

The localization of the $T \beta R$ complex to specific membrane domains is key for signalling modulation, as it dictates its internalization via different routes and determines whether or not signalling will occur [28]. Internalization of the receptor via clathrin-coated vesicles (CCV) into early endosome antigen 1 (EEA-1)-postive and SARA-containing endosomes promotes signalling [29]. In contrast, internalization via membrane rafts (membrane domains of tightly packed cholesterol-sphingolipids protein complexes) into caveolin-positive vesicles results in receptor degradation and prevents signalling [29]. The latter vesicles specifically carry the inhibitory SMAD7, which by associating with Smurf2 facilitates Smurf-mediated targeting of T $\beta R I$ for proteasome-dependent degradation [29]. Although what causes the receptors to segregate into these two different routes is not fully understood (ligand binding does not necessarily favors one route over the other [26]), it is known that the extracellular domain of T $\beta$ RII (possibly via interaction with other cell surface glycoproteins) is required for partitioning into membrane rafts [30]. Further, when T $\beta$ RIII/betaglycan is present, it recruits both T $\beta$ RII and T $\beta R I$ to non-raft membrane fractions, thus promoting SMAD signalling [31]. Taken together, these results indicate that the levels of expression of the TGF $\beta$ receptors themselves, and in particular betaglycan, dictate the extent of canonical signalling activation via modulation of receptor trafficking.

Although the three TGF $\beta$ isoforms primarily signal through the canonical SMAD2/3 pathway, numerous non-SMAD signalling pathways (referred to as non-canonical) are also activated by TGF $\beta$ ligands. These pathways include the Ras/MAPK/Erk pathway [13] the PI3K/Akt pathway [32], the TAK1-p38/JNK pathway [33], and the Par6-Polarity pathway [34]. Previous studies indicate important roles of non-canonical signalling in determining the functional outcome of TGF $\beta$ [35], including tissue repair [36,37].

Despite sharing $71 \%-76 \%$ sequence identity and signalling through the same canonical SMAD intermediates (SMAD2 and SMAD3), a growing body of evidence suggests that the three TGF $\beta$ isoforms have different physiological roles [38]. Each TGF $\beta$ isoform is transcribed from a unique promoter and has a distinct pattern of tissue expression [39]. The differences in isoform expression patterns are reinforced by non-overlapping phenotypes seen in TGF $\beta$ isoform-specific transgenic and knockout mice [38]. Some of the most well-studied examples of TGF $\beta$ isoform-specific biology are cardiac development [40], palate formation [41], and cutaneous wound healing; the latter will be discussed in Section 2.

Overall, the outcome of TGF $\beta$ signalling input is highly context-dependent, as it is the net result of numerous contributing factors, including: the specific ligand(s) present in the microenvironment; 
the bioavailability and concentration of such ligands; the cell type; the levels of signalling mediators within the cell; the extent of activation of canonical versus non-canonical signalling pathways; and the extent to which both of these branches of TGF $\beta$ signalling crosstalk with signalling inputs via other receptor systems, both in the cytoplasm and in the nucleus [4]. Importantly, increasing evidence indicates that major modifying signalling inputs are mediated by the cellular cytoskeleton in response to mechanical stimuli, such as loss of integrity of cell-cell contacts [42], cellular tension [43], and ECM stiffness $[44,45]$. Mechanotransduction of these stimuli in the presence of active TGF $\beta$ signalling results in synergistic responses between mechanosensitive transcriptional co-activators and TGF $\beta$-regulated signal transducers, such as the R-SMADs [46-48]. As discussed in more detail below, this synergy plays an important role during key steps of wound healing and regeneration, such as fibrogenesis [46,47].

\section{Cutaneous Wound Repair}

Among vertebrates, the reparative response to injury follows a stereotypical sequence of events that can be divided into three main overlapping phases: hemostasis and inflammation; proliferation; and maturation and remodeling $[49,50]$. Throughout these events, TGF $\beta$ plays a number of crucial roles that vary in a context and cell type-dependent manner. The pleiotropic effects of TGF $\beta$ include regulating cell proliferation, differentiation, migration, invasion and chemotaxis of the epithelial, fibroblastic and immune cell tissue compartments (the latter involved in inflammatory response), as well as endothelial cell proliferation, migration and invasion, and mural cell maturation (to generate functional blood vessels) during angiogenesis [1,51].

\subsection{Hemostasis and Inflammation Phase}

TGF $\beta$ isoforms demonstrate a number of dynamic interactions throughout the processes of hemostasis and inflammation. Following tissue injury, blood vessels rupture and the resulting exposure of platelets (thrombocytes) to sub-endothelial collagen causes platelet aggregation, degranulation and activation of the coagulation cascade [49]. Platelet alpha-granules are a particularly rich source of TGF $\beta 1$ (upwards of 40 to 100 times more than in other cell types) [52]. Alpha-granules also contain other TGF $\beta$ isoforms, although the ratio is heavily skewed (4000 TGF $\beta 1$ : 1 TGF $\beta 2$ : 10 TGF $\beta 3$ ) [53,54]. Platelet-induced activation of the coagulation cascade results in the formation of a fibrin clot which achieves hemostasis as well as serves as a scaffolding for the migration of inflammatory cells into the wounded tissue [49].

Following hemostasis, TGF $\beta$ next participates as a potent chemoattractant and inflammatory mediator for various types of immune cells, including neutrophils and other poly $\underline{\text { morphonuclear }}$ (PMN) cells (basophils, eosinophils, mast cells; beginning 24 to $48 \mathrm{~h}$ after wounding) [55-57] and circulating monocytes (48 to $96 \mathrm{~h}$ post-wounding) [58-60]. Curiously, TGF $\beta$ ligands are also known to antagonize other neutrophil chemoattractants, such as interleukin-8, and can suppress the ability of immune cells to transmigrate into injured tissues [56,61]. Hence, TGF $\beta$ participates in both stimulating the initial immune response, through the recruitment of PMN, and limiting the extent of the inflammatory response [56]. Whereas platelets are characterized as being rich in TGF $\beta 1$, in neutrophils, the ratio of TGF $\beta$ isoforms is biased towards TGF $\beta 3$ (12 TGF $\beta 1$ : 1 TGF $\beta 2$ : 34 TGF $\beta 3$ ), indicating the possibility of isoform-specific differences throughout the wound-healing process [54]. Following their recruitment, many subsequent roles of macrophages-including the initiation of granulation tissue formation and angiogenesis-are also known to be mediated by TGF $\beta[50,58]$.

\subsection{Proliferative Phase}

The proliferative phase involves three major TGF $\beta$-mediated events: re-epithelialization; angiogenesis; and extracellular matrix (ECM) synthesis. In response to injury, epithelial cells located at the wound margins become activated and undergo a phenotypic change characterized by an alteration of their cytoskeleton and the dissolution of cell-cell contacts [62,63]. Migration and proliferation of epithelial cells is driven by a variety of autocrine and paracrine signalling pathways (reviewed by [63] 
and [64]), of which TGF $\beta$ is one of the most extensively studied. Prior to injury, TGF $\beta 1$ in the epidermis functions as a homeostatic cytokine, blocking cell-cycle progression and suppressing epithelial hyperplasia [65-67]. Following injury, all three TGF $\beta$ isoforms promote re-epithelialization [67-69], and their abolishment (with the use of neutralizing antibodies) impairs wound closure [69-72]. However, whereas TGF $\beta 1$ acts to promote keratinocyte migration in vitro [67], TGF $\beta 3$ does not [69].

The key mechanism involved in re-epithelialization is the epithelial to mesenchymal transition (EMT) [73]. Key cellular events during EMT, including the loss of cell-cell contacts and increased motility, are driven by both canonical and non-canonical TGF $\beta$ signalling [73]. Changes in the levels of SMAD3 might play an important role in the switch of TGF $\beta$ function from a growth-suppressing cytokine in intact epithelium to an EMT-promoting one in wounded epithelium. SMAD3 mediates TGF $\beta$ 's growth-suppressive effects, and a decline in endogenous SMAD3 occurs in parallel to EMT and leads to loss of growth-inhibitory response to TGF $\beta$ during this process [74]. In agreement with these findings, mice that are heterozygous or null for SMAD3 show enhanced re-epithelialization and wound closure $[75,76]$.

Epithelial cell injuries, such as those involving disruption of the Crumbs complex that associates with the tight junction (apical cell-cell contacts), are also known to sensitize cells to TGF $\beta$-mediated EMT by enhancing nuclear translocation of SMAD2/3 via the Hippo pathway mediators TAZ (transcriptional co-activator with PDZZ-binding domain) and YAP (Ý es-associated protein) [46,77]. Interestingly, TAZ silencing prevents robust expression of alpha smooth $\underline{\text { muscle }}$ actin $(\overline{\alpha S M A})$ by TGF $\beta$ and subsequent epithelial to myofibroblast conversion in wounded epithelium [46], and skin-specific deletion of both TAZ and YAP in adult mice impairs skin regeneration after wounding [78]. This impairment was in part attributed to the role of TAZ/YAP in maintaining the stem-cell population of the basal layer of the skin [78]. Together, these observations suggest that a TGF $\beta$ and Hippo signalling crosstalk mediates TGF $\beta$ 's wound-healing properties.

Another key event during the proliferation phase is angiogenesis. Angiogenesis involves the invasion of the wound bed by capillary sprouts to create a de novo microvascular network [79-82]. Although still not fully understood, due to its context-dependency, a role for TGF $\beta$ as a modulator of angiogenesis has long been recognized [83]. TGF $\beta$ 's ability to induce angiogenesis might be linked, at least in part, to its capacity to promote vascular endothelial growth factor (VEGF) expression at the site of injury. VEGF mediates angiogenic activity during the proliferative phase of wound healing [80], and TGF $\beta$ is known to recruit VEGF-producing hematopoietic effector cells to promote angiogenesis in vivo [84]. All three TGF $\beta$ isoforms can also induce endothelial to mesenchymal transition (EndoMT) [40], which has been widely implicated in pathologic fibrosis of various organs (including the skin $[85,86]$ ), as well as the sprouting phase of angiogenesis [87].

Finally, TGF $\beta$ is involved in ECM synthesis and the recruitment of fibroblasts from the adjacent dermis [88], as well as from perivascular sources (e.g., pericytes) and bone marrow (i.e., fibrocytes) [89-91]. Once they have entered the wound bed, fibroblasts proliferate and begin synthesizing the provisional ECM (mostly collagen and fibronectin) that precedes the formation of granulation tissue proper. Granulation tissue is a transient, heavily vascularized reparative organ characterized by a loose matrix of collagen, fibronectin and hyaluronic acid interspersed with fibroblasts and macrophages $[49,50]$. TGF $\beta$ ligands play a fundamental role in fibroblast regulation and the production of granulation tissue. TGF $\beta 1$ mediates fibroblast collagen production (specifically type I and III), as well as in the inhibition of MMPs [92]. Related to this, TGF $\beta 1$-mediated signalling has been implicated in diseases characterized by excessive collagen deposition including keloids and scleroderma [92-94]. Importantly, while TGF $\beta 1$ and TGF $\beta 2$ promote collagen deposition and scar formation, TGF $\beta 3$ appears to be anti-fibrotic $[95,96]$. Hence, the combined effect of TGF $\beta 3$ and TGF $\beta 1$ is interpreted as a fine-tuning of collagen production [92,97]. As the proliferative phase of wound healing progresses, a subset of fibroblasts will differentiate into myofibroblasts and another subset will undergo apoptosis, thereby marking the beginning to the final stage of wound healing, the remodeling phase [49]. 


\subsection{Remodeling Phase}

The final phase of wound healing is remodeling, involving the apoptosis of resident cells (including fibroblasts and endothelial cells), as well as wound contracture, and the replacement of fibronectin and type III collagen in the wound bed with type I collagen [49,92]. As a result, the once highly cellular and heavily vascularized mass of granulation tissue is transformed into a largely avascular and acellular scar $[88,91]$. Wound contracture is facilitated by myofibroblasts, a population of fibroblasts that acquire a contractile phenotype, as evidenced by their expression of $\alpha$ SMA [91]. The acquisition of $\alpha$ SMA expression is controlled by TGF $\beta 1$, through SMAD-dependent and independent transcriptional activity at the $\alpha$ SMA promoter $[44,91,98]$, as well as by mechanical loading of the wound environment [91]. Curiously, myofibroblasts are absent from the wound bed during the earlier phases of wound healing when levels of TGF $\beta 1$ are at their highest [91]. One explanation is that in order to express $\alpha \mathrm{SMA}$, fibroblasts require a combination of a stiff milieu/mechanical stress and TGF $\beta 1$ [91,98]. In support of this prediction, in vitro experiments have demonstrated that even in the presence of adequate TGF $\beta 1$ levels, fibroblasts fail to transition to myofibroblasts if plated on low stiffness environments [44]. This might be related to the observation that a mechanoresistant/stiff ECM facilitates the activation of latent, ECM-sequestered TGF $\beta 1$ by the myofibroblasts themselves [45]. In this study, a stiff ECM was found to be required for integrin-mediated activation of self-produced TGF $\beta 1$ by myofibroblast, as a result of their cytoskeletal contraction caused by ECM tension [45]. In agreement with these findings, myofibroblast-populated wounds displayed a higher level of SMAD2/3 activation in stressed as compared to relaxed tissue, despite similar levels of TGF $\beta 1$ and T $\beta$ RII [45]. This suggests that during wound remodeling, TGF $\beta 1$ activation (and the consequent maintenance of the myofibroblast phenotype) is restricted to areas with a stiff ECM, equivalent to that encountered in the late-wound granulation tissue [45].

Although the mechanisms through which fibroblasts and myofibroblasts interpret their environment are not completely understood, members of the Hippo signalling pathway, such as TAZ, are likely involved in mechano-sensing the tissue environment and modulating TGF $\beta 1$ responsiveness $[46,48]$. In agreement with this notion, TAZ was shown to confer SMAD3 sensitivity to the $\alpha \mathrm{SMA}$ promoter, and to facilitate $\alpha \mathrm{SMA}$ expression in response to TGF $\beta 1$ in combination with mechanical stretch [47]. In contrast, when there was only mechanical stretch (but no TGF $\beta 1$ ), another major mechanosensitive transcriptional co-activator known as myocardin related transcription factor (MRTF), interacted with TAZ and SMAD3 to suppress SMAD3-TAZ-mediated activation of the $\alpha$ SMA promoter [47]. Together, these findings support a model whereby stretch alone promotes a limited contractile response, possibly promoting healing, while stretch plus TGF $\beta 1$ favors the formation of fibrotic tissue [47].

Similar to TGF $\beta 1$, TGF $\beta 2$ is also a potent inducer of the fibroblasts to myofibroblast transition (both in vitro and in vivo) [99]. In contrast, the role of TGF $\beta 3$ is more complex. While TGF $\beta 3$ appears to promote the acquisition of a myofibroblast phenotype in vitro, in vivo it inhibits myofibroblast formation $[96,99]$.

\subsection{Exceptions to Scar Formation in Mammals}

Among mammals it is well understood that most injuries to the skin are resolved with the formation of scar tissue. Although scar tissue acts to help restore structural integrity and homeostasis, it is a dysfunctional replacement. Conspicuously, scar tissue fails to re-develop hair follicles and glands, as well as the protein elastin and the original basket-weave collagen architecture of the dermis. As a result, scars lack the tensile strength of uninjured skin $[96,100]$. However, a number of remarkable exceptions to this mammalian scarring paradigm exist. For example, in some species of African spiny mice (Acomys), large sections of dorsal body skin can be shed (autotomized) and then regenerated scar-free, complete with hair follicles and glands [101]. These species can also regenerate through-and-through ear punch wounds, regenerating skin and cartilage [101]. Curiously, a recent qRT-PCR screen has revealed that TGF $\beta 1$, typically considered a pro-inflammatory cytokine, 
is significantly upregulated during wound healing in Acomys: a seven-fold increase compared to uninjured skin; in mice (which scar) the increase is only three-fold [102].

Another notable example comes from fetal mammals. Many mammals (including humans, rats, mice, pigs and monkeys) are capable of scar-free cutaneous healing in the early- to mid-gestation stages of fetal development $[88,103,104]$. Although details of the mechanisms permitting scar-free fetal wound healing remain to be fully elucidated, a role for TGF $\beta$ has been established [88]. One of the key observations is that the expression of TGF $\beta$ isoforms differs between the fetal and adult responses to injury. More specifically, whereas adult cutaneous wounds demonstrate high levels of TGF $\beta 1$ and TGF $\beta 2$, but low levels of TGF $\beta 3$, the expression pattern in the fetal wound is the reverse (high expression of TGF $\beta 3$, low expression of TGF $\beta 1$ and TGF $\beta 2)[105,106]$. If fetal wounds are treated with exogenous TGF $\beta 1$, the result is scarification [107]. Alternatively, if adult wounds are treated with exogenous TGF $\beta 3$, or if endogenous TGF $\beta 1$ and TGF $\beta 2$ are blocked (e.g., with neutralizing antibodies), the severity of scarring is reduced [96]. These observations combined with numerous other examples from adult wound healing place TGF $\beta$ isoforms, and in particular their relative ratios, as a driving force in determining the balance between tissue repair and tissue regeneration. To better understand this phenomenon, the next section examines the role of TGF $\beta$ isoforms in species that possess the unique ability, like fetal wounds, to heal without scarification.

The involvement of specific TGF $\beta$ isoforms in the three phases of cutaneous wound healing is summarized in Figure 1.

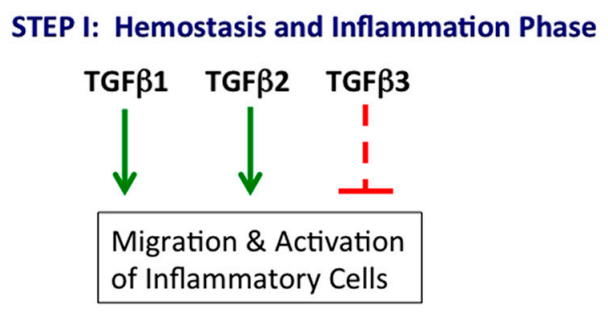

STEP II: Proliferative Phase

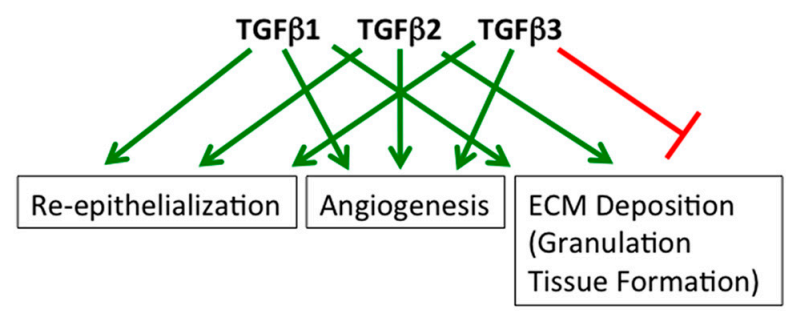

STEP III: Remodeling Phase

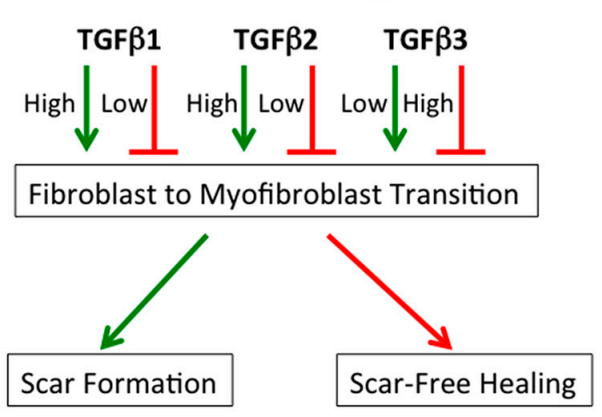

Figure 1. TGF $\beta$ isoforms in cutaneous wound healing. TGF $\beta 1$, TGF $\beta 2$ and TGF $\beta 3$ play central roles in all three phases of wound healing. Generally, TGF $\beta 1$ and TGF $\beta 2$ are stimulatory, while TGF $\beta 3$ is inhibitory. However, TGF $\beta 3$ can also stimulate specific processes (e.g., re-epithelialization). Green arrow: stimulatory; continuous red line: inhibitory; dashed red line: potentially inhibitory, inferred from relative levels at the beginning (low) and end (high) of the hemostasis and inflammation phase. 


\section{Multi-Tissue Regeneration}

\subsection{Blastema Formation}

Amongst vertebrates, many of the most striking examples of multi-tissue regeneration begin with the formation of a mass of mesenchymal-like cells at the wound site-the blastema [108]. Although the blastema appears to be composed of a homogeneous population of undifferentiated cells, various recent studies have demonstrated that blastema cells are actually a heterogeneous pool of lineage-restricted progenitor cells [109-111]. Consequently, blastema cells are not a pluripotent (or perhaps even multipotent) population, but instead retain a memory of their germ-layer origin (axolotls: [109], mouse digits: [111]). Details of blastema formation remain poorly understood, but it is predicted to be the result of either reprogramming events occurring amongst the different lineage restricted cell populations, or rapid expansion of tissue-specific stem-cell populations, or a combination of both [109-111].

One of the earliest signs of blastema-mediated (i.e., epimorphic) regeneration is the formation of a wound epithelium. The wound epithelium first forms as original epidermal cells surrounding the wound migrate across the site of injury [112]. Once re-epithelialization is complete, the wound epithelium begins to thicken, resulting in a capping structure that closely resembles the apical ectodermal ridge (AER) observed during limb development $[113,114]$. In addition to thickness, the wound epithelium also differs from the pre-wounding epidermis in that it lacks the distinctive stratified appearance, basal keratinocyte polarity and a mature basal lamina $[115,116]$. Furthermore, the wound epithelium demonstrates unique protein and gene expression profiles compared to normal epithelium [117-119]. Independent reports have established that the wound epithelium is key for blastema induction and proliferation $[114,120]$.

\subsection{TGF $\beta$ in Multi-Tissue Regeneration}

One of the best-documented investigative approaches to demonstrate the requirement for TGF $\beta$ signalling during in vivo regeneration involves the use of the potent small molecule inhibitor SB-431542. This is a selective inhibitor of the type I receptors ALK4, ALK5 and ALK7, and acts to inhibit phosphorylation of SMAD2 and SMAD3 [121]. In axolotls, TGF $\beta 1$ mRNA is normally upregulated by blastema cells during the early (preparatory) phase of limb regeneration [122]. Moreover, if amputated animals are treated with SB-431542, cell proliferation is halted, the blastema fails to form, and regeneration is prevented [122]. Similarly, spontaneous tail regeneration by Xenopus tadpoles involves an increase in phosphorylated SMAD2 (pSMAD2) expression, as well as an upregulation of TGF $\beta$ family members $x$ TGF $\beta 2$ (similar to TGF $\beta 2$ ), xTGF $\beta 5$ (similar to TGF $\beta 1$ ), as well as $x$ GDF11 and $x$ Activin- $\beta$ A [123]. When amputated tadpoles are treated with SB-431542, wound healing is blocked, cell proliferation is reduced, and the blastema fails to form [123].

Other evidence supporting the involvement of TGF $\beta$ in regeneration comes from experiments with zebrafish. Following tail fin amputation, spontaneous regeneration of the appendage involves a significant upregulation of activin- $\beta A$, one of the subunits of the activin complexes $A B$ and $B$ [124]. Treatment with SB-431542 results in an abnormal wound epidermis, reduced cell proliferation, and the failure of the blastema to properly form. To expand these findings, the authors then used knockdown morpholinos to silence activin- $\beta$ A expression. The result was a $50 \%$ reduction in regenerated tail size [124]. Combined, these experimental observations support the role of TGF $\beta$ signalling in cell proliferation, in addition to blastema formation and maintenance.

TGF $\beta$ signalling is also involved in zebrafish cardiac regeneration following cryoinjury. The cryoinjury method results in localized cell death along the ventricular wall, and has the advantage of histologically mimicking a myocardial infarction otherwise characteristic of mammals, including humans [125]. Myocardial repair is a two-step process, beginning with scar formation, which is then gradually replaced with new cardiac muscle [125]. During myocardial repair, all three TGF $\beta$ isoforms (TGF $\beta 1$, TGF $\beta 2$, TGF $\beta 3$ ), as well as activin $\beta B$ (but not activin $\beta A$ ) were upregulated [126]. This increase in TGF $\beta$ ligands corresponds to a robust induction of pSMAD3 in both the injured 
myocardium and the uninjured myocardium directly adjacent to the wound, confirming activation of the TGF $\beta$ signalling pathway [126]. When cryoinjured fish were treated with SB-431542, myocardial regeneration failed. This regenerative failure is the result of both a suppression of initial collagen synthesis, thus limiting the early formation of a scar, combined with the inhibition of cardiomyocyte proliferation [126].

A possible role for activin- $\beta$ A during regeneration has also been proposed for the leopard gecko following tail loss. Similar to Xenopus tadpoles, cells of the leopard gecko's wound epithelium and blastema demonstrate widespread expression of pSMAD2 [127]. In order to identify the ligand(s) responsible for SMAD activation, a qRT-PCR screen was performed (including TGF $\beta 1$, TGF $\beta 2$, TGF $\beta 3$, and activin- $\beta A$ ), but only activin- $\beta A$ was significantly upregulated [127]. Combined, these experiments underscore the necessary and highly conserved role of TGF $\beta$ signalling in spontaneous regeneration, and point towards the activins as potential key players.

\subsubsection{Murphy Roths Large (MRL) Mice}

Murphy $\underline{\text { Roths }}$ Large (MRL/Mpj) mice were originally developed by selective inbreeding for studies of systemic lupus erythematosus, an autoimmune condition with debilitating clinical effects. Surprisingly, however, this mouse strain possesses an exaggerated healing response characterized by the ability to close ear hole wounds and to heal injuries to the myocardium $[128,129]$. The mechanism behind this increased regenerative ability remains poorly understood, but various lines of evidence point to a role for TGF $\beta$ signalling. First, MRL mice demonstrate enhanced levels of the three TGF $\beta$ isoforms in various tissues [130], and increased TGF $\beta$ response to bacterial infection or lipopolysaccharide (LPS) challenge, compared to wild-type mice [131]. Second, two loci strongly correlating to autoimmunity on chromosome 7 and 12 (and possibly responsible for the lupus phenotype in the MRL mice) co-localize with the genes for TGF $\beta 1$ and TGF $\beta 3$ (respectively) suggesting a possible, albeit speculative, mechanistic link [131,132]. Supporting this possibility, in skin graft models employing MRL mice skin or the skin of a haplotypically identical mouse (B10.BR) on B10.BR recipients suggests that the improved tissue repair in MLR mice is mediated by reduced pro-inflammatory response possibly mediated by TGF $\beta$ signalling [133].

\subsubsection{TGF $\beta 1$ Receptor Mutant Mice}

In an attempt to identify candidate genes involved in tissue regeneration, a forward genetics screen using $\mathrm{N}$-ethyl- $\mathrm{N}$-nitrosurea was used to generate a mouse strain with a fast-healing phenotype identified by ear hole wounding [134]. This phenotype was mapped back to a $G$ to A transition in the gene that codes the T $\beta R I$, resulting in a substitution of a conserved arginine residue in the regulatory domain of T $\beta$ RI. This mutation leads to a modest increase in TGF $\beta 1$ responsiveness (two-fold increase as measured by a PAI luciferase vector), as well as a slight increase in SMAD2 phosphorylation [134]. Unfortunately, the responsiveness to other isoforms of TGF $\beta$ was not evaluated; however, nearly three-quarters of known TGF $\beta$-responsive genes were not affected by this mutation, thus suggesting tailored modification to the TGF $\beta$ signalling pathway. This result demonstrates that receptor-level modifications can lead to phenotypically relevant changes leading to an enhanced regenerative ability, and this situation could be analogous to isoform-specific differences in receptor activation.

\section{TGF $\beta$ Signalling Targeting in Wound Healing and Tissue Regeneration}

As TGF $\beta$ signalling drives a number of pathologic conditions, TGF $\beta$-targeting agents have been developed for medical applications in oncology, fibroproliferative disorders, vascular diseases, and wound healing (reviewed in [135]). However, the clinical development of these agents has been challenging, in part due to the fact that TGF $\beta$ ligands are highly cell-type and context-dependent. Despite this limitation, the strategies discussed below hold therapeutic promise as potential enhancers of regenerative capacity. 


\subsection{Small Molecule Inhibitors}

There are a number of $\underline{\text { small }}$ molecule inhibitors (SMI) of type II and type I TGF $\beta$ receptor kinases, but only the latter have progressed to phase I/II clinical trials (reviewed in [136]). SB-431542, a T $\beta$ RI SMI discussed above, was extensively used in in vivo studies that demonstrated the role of canonical TGF $\beta$ signalling in tissue regeneration. However, more specific inhibitors have been developed since. One of these is LY2157299 (Eli Lilly and Company, Indianapolis, IN: Clinicaltrials.gov: NCT01373164), which has progressed to phase II in the oncology setting (reviewed in [137]). Although the application of this and similar SMIs to the improvement of healing and/or regeneration might be limited by their broad inhibition of signalling by different TGF $\beta$ family ligands (some of which may be crucial to these processes $[123,124])$, preclinical studies indicate potential in specific settings. For instance, a study evaluating the role of TGF $\beta$ in muscle regeneration found that TGF $\beta 1$ serum levels were elevated in older mouse and humans, and this effect was associated with reduced capacity of satellite cells to regenerate muscle in aged individuals [138]. In this study, systemic treatment of older mice with an SMI inhibitor of T $\beta$ RI ALK4, 5 and 7 (A83-01), but not a neutralizing antibody or decoy receptor, restored the reparative capacity of old muscle [138]. A SMI of TßRI (CAS-446859-33-2) was also observed to improve cardiomyoblast-mediated regeneration in mice [139]. Although little is known of the applicability of T $\beta$ RI SMIs to improve wound healing, subconjunctival administration of SB-431542 was shown to reduce scar formation after glaucoma surgery in rabbits [140]. As these inhibitors progress through oncological clinical trials, it will be interesting to see how patients fare in the context of post-surgical wound healing following neoadjuvant therapy, as well as overall wound-healing capacity during and after adjuvant treatment.

Another target of SMI are integrins. Previous studies have determined that various integrins (e.g., $\alpha_{v} \beta_{1}$, ) mediate non-proteolytic activation of TGF $\beta 1$ [141,142]. A SMI of the $\alpha_{v} \beta_{1}$ integrin (c8) has recently been developed, and used to treat two different mouse models of pathologic fibrosis: induced pulmonary fibrosis and induced hepatic fibrosis [142]. Subcutaneous treatment with c8 resulted in a reduction of collagen deposition in both models. The authors concluded that inhibition of $\alpha_{\mathrm{v}} \beta_{1}$ integrin by c8 protects against TGF $\beta 1$-mediated fibrosis, although other potential integrin-dependent but TGF $\beta$-independent anti-fibrotic mechanisms may also participate [142].

\subsection{Monoclonal Antibodies}

Compared to SMI, monoclonal antibodies have several distinct advantages, including target ligand specificity and extracellular mode of action. This is particularly relevant to tissue regeneration, as isoform-specific antibodies have the capacity to neutralize specific "inhibitory" ligands in the extracellular space. A number of antibodies directed against TGF $\beta$ ligands have progressed through various phases of clinical development [136]. One particularly promising example is fresilimumab (GC-1008, Genzyme/Sanofi, Cambridge, MA, USA), a humanized antibody that targets TGF $\beta 1$, TGF $\beta 2$ and TGF $\beta 3$ ligands. To date, fresilimumab has progressed through phase I clinical trials in focal segmental glomerular sclerosis (NCT00464321), systemic sclerosis (NCT01284322) and idiopathic pulmonary fibrosis (IPF)(NCT0125385) [143].

Isoform-specific monoclonal antibodies against both TGF $\beta 1$ (metelimumab, CAT-192) and TGF $\beta 2$ (lerdelimumab, CAT-152) have also been developed (Cambridge Antibody Technology, Cambridge, UK; now part of AztraSeneca). Lerdelimumab (targeting TGF $\beta 2$ ) did show promise in glaucoma surgery by reducing scarring during subconjunctival wound healing in a randomized study in rabbits [144]. It also showed promise in a similar phase I/II study, in which the antibody was locally administered (subconjunctival injections) pre- and post-operatively to humans [145]. Although a phase III study that investigated its use in preventing scarring after first-time trabeculectomy for primary open-angle glaucoma (POAG) or chronic angle-closure glaucoma (CACG) did not find it beneficial [146], lederlimumab was found to be safe in this and the previously mentioned human trials. Despite discontinued clinical development of both lerdelimumab and metelimumab [147], pre-clinical and clinical studies with these or similar antibodies in different scenarios of healing/regeneration are 
necessary, as they may still provide the ability for TGF $\beta$ isoform-specific modulation of the wound environment in favour of scar-free healing, with potentially minor side effects.

\subsection{Ligand Traps/Decoy Receptors}

Several TGF $\beta$ ligand traps have been developed based on the peptide sequence of the TGF $\beta$ co-receptor betaglycan (a T $\beta$ RIII). One such ligand trap, referred to as P144 or disitertide, is a peptide encompassing amino acids $730-743$ from the membrane-proximal ligand-binding domain of betaglycan. P144 acts by interfering with binding and activity of TGF $\beta 1$ [148]. Systemic (intraperitoneal) treatment with P144 prevents fibrosis following a chemically induced liver injury in rats [148], while its topical administration ameliorates both bleomycin-induced skin fibrosis in mice [149] and human scar hypertrophy in a xenotransplant model in mice [150]. P144 (disitertide topical cream) is ready to enter phase II clinical trials for potential application in the treatment of localized scleroderma, and phase IIb for systemic sclerosis (http:/ /dignabiotech.com).

\subsection{Antisense Oligonucleotides}

Another approach to target TGF $\beta$ signalling consists of blocking TGF $\beta$ ligand gene expression, or the expression of specific SMADs, through the use of anti-sense oligonucleotides (ASON). These short polymers inhibit target gene expression by binding to target mRNA sequences and blocking mRNA translation. Trabedersen, developed by Antisense Pharma (now Isarna Therapeutics, Munich, Germany), is a TGF $\beta 2$-specific ASON with demonstrated efficiency in phase II and III trials in oncology applications, specifically glioblastoma (reviewed by [136]). The evaluation of TGF $\beta$ and SMAD-specific oligonucleotides in wound healing and regeneration is still at the preclinical stage, but the results so far are encouraging. Both TGF $\beta 2$-targeting and TGF $\beta 1$-specific ASONs showed a reduction in post-operative scarring after a single administration at the time of surgery in two different animal models of human glaucoma filtration surgery [151]. In this study, TGF $\beta 2$-targeting ASON was determined to be the most effective treatment. A more recent study demonstrated that SMAD3-specific ASON prevents scarring following flexor tendon repair surgery [152]. One advantage of the anti-sense oligonucleotide therapy seems to be a long-lasting effect [151], which might reduce the number of necessary post-surgical administrations.

\subsection{Indirect TGF $\beta$-targeting Agents}

Anti-TGF $\beta$ signalling effects and associated regenerative properties have also been observed in biologically active molecules produced by plants and animals or that were chemically synthesized; some have already been approved for human and veterinary medicine. These include curcumin [153], decorin [154], halofuginone [155], quercetin, asiaticoside, and tetrandine [156].

An emerging example is the angiotensin receptor blocker Losartan. In addition to its widespread use in treating hypertension, Losartan also inhibits TGF $\beta$-induced activation of canonical and non-canonical signalling mediators [157]. Related to this, it shows some promise for patients suffering from Marfan syndrome and possibly other inherited connective tissue disorders where excessive TGF $\beta$ signalling predisposes to aortic root aneurism and/or skeletal muscle myopathy $[157,158]$. Losartan treatment at specific doses and schedules also improves muscle healing in a mouse model of contusion-induced muscle injury [159], and facilitates epidermal wound regeneration in a model of streptozotocin-induced diabetes in mice [160].

Another promising compound is pirfenidone (PFD), an anti-fibrotic, anti-inflammatory, and antioxidant with demonstrated abilities in down-regulating a number of profibrotic cytokines, including TGF $\beta 1$ [161]. PFD has been licensed in many countries (except for the United States) for the treatment of idiopathic pulmonary fibrosis, a chronic lung disease resulting from an aberrant wound-healing circuitry in pulmonary epithelium [162]. PFD nanoparticles, administered $1 \mathrm{~h}$ post-injury and daily for up to 7 days, promoted re-epithelization, and decreased collagen type I synthesis and cornea opacity in a mouse model of alkali-induced corneal burn [163]. A more recent 
study on excisional wound healing in mice tested the effect of PFD delivered using several different topical modalities. Regardless of mode of delivery, PFD was found to accelerate wound contraction and significantly reduce TGF $\beta$ expression as well as scarring [164].

\subsection{Recombinant TGF $\beta$}

An alternative strategy to the pharmacological approaches described above involves the application of exogenous TGF $\beta$ ligands, most notably the recombinant TGF $\beta 3$ (Avotermin/Juvista) produced by Renovo (Manchester, UK) [165]. As demonstrated by three randomized, double-blind, placebo-controlled phase II clinical trials (NCT00594581, NCT00432211 and NCT00430326), avotermin treatment is safe, well tolerated, and offers a significant improvement in scar appearance [166-168]. Data from in vitro and pre-clinical studies (reviewed in [169]) also indicate that avotermin enhances chondrogenesis. Of note is the proposed use of cartilage-ECM-derived scaffolds that might allow for controlled release of TGF 33 to promote chondrogenesis of intrapatellar fat pad-derived stem cells for use in articular cartilage regeneration [170].

The use of recombinant ligand to promote tissue regeneration might not be limited to TGF $\beta 3$. A recent study comparing the effect of TGF $\beta 1$ and BMP2 on calvarial defect healing and suture regeneration in rabbits, suggests TGF $\beta 1$ to be a superior factor in this particular setting, by promoting bone healing via the native intramembranous ossification pathway [171].

\section{Conclusions}

Both canonical and non-canonical signalling activated by TGF $\beta$ isoforms 1, 2 and 3, as well as activin play crucial roles in wound healing and multi-tissue regeneration across vertebrates. The ultimate outcome of this signalling depends on an exquisite balance of ligand levels, the cell type, and the micro-environmental context in which the ligand is presented, including the stiffness of the ECM. In adult mammals, high levels of TGF $\beta 1$ and TGF $\beta 2$, and low levels of TGF $\beta 3$ facilitate scar-forming healing, while in fetal mammals, high levels of TGF $\beta 3$ and low levels of TGF $\beta 1$ and TGF $\beta 2$ favour scar-free healing. ALK-mediated signalling by TGF $\beta 1$, TGF $\beta 2$ and activin $\beta$ A drives early stages of blastema-mediated, multi-tissue regeneration in axolotls, Xenopus, zebrafish and possibly leopard geckos, with one or more of these ligands playing a prominent role, depending on the species. Canonical signalling by distinct TGF $\beta$ isoforms also modulate repair of cardiac and skeletal muscle, bone, and cartilage. Based on the knowledge accumulated over the last three decades, a number of different strategies to modulate TGF $\beta$ signalling are either under investigation or have been approved (e.g., recombinant-human TGF $\beta 3$ ) to promote scar-free wound healing and/or regeneration of specific tissues in humans. Further research on regeneration-competent vertebrates is encouraged, as this will lead to the identification of the elements lacking in regeneration-incompetent vertebrates, thus informing pharmacological strategies of broad applicability to both human and veterinary regenerative medicine.

Acknowledgments: The authors thank the National Science and Engineering Research Council (NSERC) of Canada for providing funds to M.K.V. (Grant \# 400358) and A.V.P. (Grant \# 400419) to develop the initial studies that led to this review, and gratefully acknowledge the insightful comments by two anonymous reviewers.

Author Contributions: All three authors: R.W.D.G, M.K.V., and A.V.P. conceived the specific topics of this review and wrote the paper. A.V.P. designed Figure 1.

Conflicts of Interest: The authors declare no conflict of interest. The founding sponsors had no role in the writing of the manuscript, and in the decision to publish.

\section{Abbreviations}

The following abbreviations are used in this manuscript:

aSMA Alpha Smooth Muscle Actin

AER Apical Ectodermal Ridge

ALK Activin-Like Kinase 


\begin{tabular}{|c|c|}
\hline ASON & Anti-Sense Oligonucleotides \\
\hline BMP & Bone Morphogenic Protein \\
\hline CACG & Chronic Angle Closure Glaucoma \\
\hline ECM & Extracellular Matrix \\
\hline EEA-1 & Early Endosome Antigen 1 \\
\hline EMT & Epithelial to Mesenchymal Transition \\
\hline EndoMT & Endothelial to Mesenchymal Transition \\
\hline Erk & Extracellular Signal Regulated Kinases \\
\hline GDF & Growth and Differentiation Factor \\
\hline JNK & C-Jun N-Terminal Kinases \\
\hline LPS & Lipopolysaccharide \\
\hline MAPK & Mitogen-Activated Protein Kinases \\
\hline MMP & Matrix Metalloproteinase \\
\hline MRL & Murphy Roths Large \\
\hline MRTF & Myocardin-Related Transcription Factor \\
\hline MIS & MullerianInhibiting Substances \\
\hline PAI & Plasminogen Activator Inactivator \\
\hline PFD & Pirfenidone \\
\hline PI3K & Phosphatidylinositide 3 Kinases \\
\hline PMN & Polymorphonuclear Cells \\
\hline POAG & Primary Open Angle Glaucoma \\
\hline SAPK & Stress-Activated Protein Kinases \\
\hline SMAD & Small Mothers against Decapentaplegic \\
\hline SMI & Small Molecule Inhibitors \\
\hline TAZ & Transcriptional Coactivator with PDZ-Binding Motif \\
\hline $\mathrm{T} \beta \mathrm{RI}$ & Transforming Growth Factor Beta Receptor I \\
\hline $\mathrm{T} \beta \mathrm{RII}$ & Transforming Growth Factor Beta Receptor II \\
\hline T $\beta$ RIII & Transforming Growth Factor Beta Receptor III \\
\hline TGF $\beta$ & Transforming Growth Factor Beta \\
\hline VEGF & Vascular Endothelial Growth Factor \\
\hline YAP & Yes-Associated Protein \\
\hline
\end{tabular}

\section{References}

1. Viloria-Petit, A.; Richard, A.; Zours, S.; Jarad, M.; Coomber, B.L. Role of transforming growth factor beta in angiogenesis. In Biochemical Basis and Therapeutic Implications of Angiogenesis, Advances in Biochemistry in Health and Disease; Mehta, J., Dhalla, N.S., Eds.; Springer: New York, NY, USA, 2013; Volume 6, pp. $23-45$.

2. Antsiferova, M.; Werner, S. The bright and the dark sides of activin in wound healing and cancer. J. Cell Sci. 2012, 125, 3929-3937. [CrossRef] [PubMed]

3. Bragdon, B.; Moseychuk, O.; Saldanha, S.; King, D.; Julian, J.; Nohe, A. Bone morphogenetic proteins: A critical review. Cell. Signal. 2011, 23, 609-620. [CrossRef] [PubMed]

4. Massague, J. Tgfb signalling in context. Nat. Rev. Mol. Cell Biol. 2012, 13, 616-630. [CrossRef] [PubMed]

5. Simakov, O.; Kawashima, T.; Marletaz, F.; Jenkins, J.; Koyanagi, R.; Mitros, T.; Hisata, K.; Bredeson, J.; Shoguchi, E.; Gyoja, F.; et al. Hemichordate genomes and deuterostome origins. Nature 2015, 527, 459-465. [CrossRef] [PubMed]

6. Moustakas, A.; Heldin, C.H. The regulation of tgfb signal transduction. Development 2009, 136, 3699-3714. [CrossRef] [PubMed]

7. Oshimori, N.; Fuchs, E. The harmonies played by tgf-beta in stem cell biology. Cell Stem Cell 2012, 11, 751-764. [CrossRef] [PubMed]

8. Wu, M.Y; Hill, C.S. Tgf-beta superfamily signaling in embryonic development and homeostasis. Dev. Cell 2009, 16, 329-343. [CrossRef] [PubMed]

9. Annes, J.P.; Munger, J.S.; Rifkin, D.B. Making sense of latent tgfb activation. J. Cell Sci. 2003, 116, $217-224$. [CrossRef] [PubMed]

10. Munger, J.S.; Sheppard, D. Cross talk among tgf-beta signaling pathways, integrins, and the extracellular matrix. Cold Spring Harbor Perspect. Biol. 2011, 3, a005017. [CrossRef] [PubMed]

11. Robertson, I.B.; Rifkin, D.B. Unchaining the beast; insights from structural and evolutionary studies on tgfb secretion, sequestration, and activation. Cytokine Growth Factor Rev. 2013, 24, 355-372. [CrossRef] [PubMed] 
12. Heldin, C.H.; Landstrom, M.; Moustakas, A. Mechanism of tgf-beta signaling to growth arrest, apoptosis, and epithelial-mesenchymal transition. Curr. Opin. Cell Biol. 2009, 21, 166-176. [CrossRef] [PubMed]

13. Lee, M.K.; Pardoux, C.; Hall, M.C.; Lee, P.S.; Warburton, D.; Qing, J.; Smith, S.M.; Derynck, R. Tgf-beta activates erk map kinase signalling through direct phosphorylation of shca. EMBO J. 2007, 26, 3957-3967. [CrossRef] [PubMed]

14. Huminiecki, L.; Goldovsky, L.; Freilich, S.; Moustakas, A.; Ouzounis, C.; Heldin, C.H. Emergence, development and diversification of the tgf-beta signalling pathway within the animal kingdom. BMC Evol. Biol. 2009, 9, 28. [CrossRef] [PubMed]

15. Goumans, M.J.; Liu, Z.; ten Dijke, P. Tgf-beta signaling in vascular biology and dysfunction. Cell. Res. 2009, 19, 116-127. [CrossRef] [PubMed]

16. Wrana, J.L.; Attisano, L.; Wieser, R.; Ventura, F.; Massague, J. Mechanism of activation of the tgf-beta receptor. Nature 1994, 370, 341-347. [CrossRef] [PubMed]

17. Van Meeteren, L.A.; Goumans, M.J.; ten Dijke, P. Tgf-beta receptor signaling pathways in angiogenesis; emerging targets for anti-angiogenesis therapy. Curr. Pharm. Biotechnol. 2011, 12, 2108-2120. [CrossRef] [PubMed]

18. Maring, J.A.; Trojanowska, M.; ten Dijke, P. Role of endoglin in fibrosis and scleroderma. Int. Rev. Cell Mol. Biol. 2012, 297, 295-308. [PubMed]

19. Bilandzic, M.; Stenvers, K.L. Reprint of: Betaglycan: A multifunctional accessory. Mol. Cell. Endocrinol. 2012, 359, 13-22. [CrossRef] [PubMed]

20. Macias, M.J.; Martin-Malpartida, P.; Massague, J. Structural determinants of smad function in tgf-beta signaling. Trends Biochem. Sci. 2015, 40, 296-308. [CrossRef] [PubMed]

21. Massague, J.; Seoane, J.; Wotton, D. Smad transcription factors. Genes Dev. 2005, 19, 2783-2810. [CrossRef] [PubMed]

22. Tsukazaki, T.; Chiang, T.A.; Davison, A.F.; Attisano, L.; Wrana, J.L. SARA, a FYVE domain protein that recruits Smad2 to the TGFbeta receptor. Cell 1998, 95, 779-791. [CrossRef]

23. Tang, W.B.; Ling, G.H.; Sun, L.; Liu, F.Y. Smad anchor for receptor activation (SARA) in TGF-beta signaling. Front. Biosci. 2010, 2, 857-860.

24. Bakkebo, M.; Huse, K.; Hilden, V.I.; Forfang, L.; Myklebust, J.H.; Smeland, E.B.; Oksvold, M.P. SARA is dispensable for functional TGF-beta signaling. FEBS Lett. 2012, 586, 3367-3372. [CrossRef] [PubMed]

25. Varelas, X.; Sakuma, R.; Samavarchi-Tehrani, P.; Peerani, R.; Rao, B.M.; Dembowy, J.; Yaffe, M.B.; Zandstra, P.W.; Wrana, J.L. Taz controls smad nucleocytoplasmic shuttling and regulates human embryonic stem-cell self-renewal. Nat. Cell Biol. 2008, 10, 837-848. [CrossRef] [PubMed]

26. Izzi, L.; Attisano, L. Regulation of the TGFbeta signalling pathway by ubiquitin-mediated degradation. Oncogene 2004, 23, 2071-2078. [CrossRef] [PubMed]

27. Liang, M.; Liang, Y.Y.; Wrighton, K.; Ungermannova, D.; Wang, X.P.; Brunicardi, F.C.; Liu, X.; Feng, X.H.; Lin, X. Ubiquitination and proteolysis of cancer-derived smad4 mutants by scfskp2. Mol. Cell. Biol. 2004, 24, 7524-7537. [CrossRef] [PubMed]

28. Kardassis, D.; Murphy, C.; Fotsis, T.; Moustakas, A.; Stournaras, C. Control of transforming growth factor beta signal transduction by small gtpases. FEBS J. 2009, 276, 2947-2965. [CrossRef] [PubMed]

29. Di Guglielmo, G.M.; le Roy, C.; Goodfellow, A.F.; Wrana, J.L. Distinct endocytic pathways regulate tgf-beta receptor signalling and turnover. Nat. Cell Biol. 2003, 5, 410-421. [CrossRef] [PubMed]

30. Luga, V.; McLean, S.; le Roy, C.; O'Connor-McCourt, M.; Wrana, J.L.; di Guglielmo, G.M. The extracellular domain of the tgfbeta type II receptor regulates membrane raft partitioning. Biochem. J. 2009, 421, 119-131. [CrossRef] [PubMed]

31. McLean, S.; di Guglielmo, G.M. Tgf beta (transforming growth factor beta) receptor type III directs clathrin-mediated endocytosis of tgf beta receptor types I and II. Biochem. J. 2010, 429, 137-145. [CrossRef] [PubMed]

32. Yi, J.Y.; Shin, I.; Arteaga, C.L. Type I transforming growth factor beta receptor binds to and activates phosphatidylinositol 3-kinase. J. Biol. Chem. 2005, 280, 10870-10876. [CrossRef] [PubMed]

33. Sorrentino, A.; Thakur, N.; Grimsby, S.; Marcusson, A.; von Bulow, V.; Schuster, N.; Zhang, S.; Heldin, C.H.; Landstrom, M. The type I tgf-beta receptor engages traf6 to activate tak1 in a receptor kinase-independent manner. Nat. Cell Biol. 2008, 10, 1199-1207. [CrossRef] [PubMed] 
34. Ozdamar, B.; Bose, R.; Barrios-Rodiles, M.; Wang, H.R.; Zhang, Y.; Wrana, J.L. Regulation of the polarity protein par6 by tgfb receptors controls epithelial cell plasticity. Science 2005, 307, 1603-1609. [CrossRef] [PubMed]

35. Zhang, Y.E. Non-smad pathways in tgf-beta signaling. Cell. Res. 2009, 19, 128-139. [CrossRef] [PubMed]

36. Saika, S.; Okada, Y.; Miyamoto, T.; Yamanaka, O.; Ohnishi, Y.; Ooshima, A.; Liu, C.Y.; Weng, D.; Kao, W.W. Role of p38 map kinase in regulation of cell migration and proliferation in healing corneal epithelium. Investig. Ophthalmol. Vis. Sci. 2004, 45, 100-109. [CrossRef]

37. Secker, G.A.; Shortt, A.J.; Sampson, E.; Schwarz, Q.P.; Schultz, G.S.; Daniels, J.T. Tgfb stimulated re-epithelialisation is regulated by ctgf and ras/mek/erk signalling. Exp. Cell Res. 2008, 314, 131-142. [CrossRef] [PubMed]

38. Laverty, H.G.; Wakefield, L.M.; Occleston, N.L.; O'Kane, S.; Ferguson, M.W. Tgf-beta3 and cancer: A review. Cytokine Growth Factor Rev. 2009, 20, 305-317. [CrossRef] [PubMed]

39. Roberts, A.B.; Kim, S.J.; Noma, T.; Glick, A.B.; Lafyatis, R.; Lechleider, R.; Jakowlew, S.B.; Geiser, A.; O'Reilly, M.A.; Danielpour, D.; et al. Multiple forms of tgf-beta: Distinct promoters and differential expression. Ciba Found. Symp. 1991, 157, 7-15; discussion 15-28. [PubMed]

40. Mercado-Pimentel, M.E.; Runyan, R.B. Multiple transforming growth factor-beta isoforms and receptors function during epithelial-mesenchymal cell transformation in the embryonic heart. Cells Tissues Organs 2007, 185, 146-156. [CrossRef] [PubMed]

41. Nawshad, A.; LaGamba, D.; Hay, E.D. Transforming growth factor beta (tgfb) signalling in palatal growth, apoptosis and epithelial mesenchymal transformation (emt). Arch. Oral Biol. 2004, 49, 675-689. [CrossRef] [PubMed]

42. Fan, L.; Sebe, A.; Peterfi, Z.; Masszi, A.; Thirone, A.C.; Rotstein, O.D.; Nakano, H.; McCulloch, C.A.; Szaszi, K.; Mucsi, I.; et al. Cell contact-dependent regulation of epithelial-myofibroblast transition via the rho-rho kinase-phospho-myosin pathway. Mol. Biol. Cell. 2007, 18, 1083-1097. [CrossRef] [PubMed]

43. Gomez, E.W.; Chen, Q.K.; Gjorevski, N.; Nelson, C.M. Tissue geometry patterns epithelial-mesenchymal transition via intercellular mechanotransduction. J. Cell. Biochem. 2010, 110, 44-51. [CrossRef] [PubMed]

44. Arora, P.D.; Narani, N.; McCulloch, C.A. The compliance of collagen gels regulates transforming growth factor-beta induction of alpha-smooth muscle actin in fibroblasts. Am. J. Pathol. 1999, 154, 871-882. [CrossRef]

45. Wipff, P.J.; Rifkin, D.B.; Meister, J.J.; Hinz, B. Myofibroblast contraction activates latent tgf-beta1 from the extracellular matrix. J. Cell Biol. 2007, 179, 1311-1323. [CrossRef] [PubMed]

46. Speight, P.; Nakano, H.; Kelley, T.J.; Hinz, B.; Kapus, A. Differential topical susceptibility to tgfb in intact and injured regions of the epithelium: Key role in myofibroblast transition. Mol. Biol. Cell 2013, 24, 3326-3336. [CrossRef] [PubMed]

47. Speight, P.; Kofler, M.; Szaszi, K.; Kapus, A. Context-dependent switch in chemo/mechanotransduction via multilevel crosstalk among cytoskeleton-regulated mrtf and taz and tgfbeta-regulated smad3. Nat. Commun. 2016, 7, 11642. [CrossRef] [PubMed]

48. Dupont, S. Role of yap/taz in cell-matrix adhesion-mediated signalling and mechanotransduction. Exp. Cell Res. 2016, 343, 42-53. [CrossRef] [PubMed]

49. Barbul, A.; Efron, D.T.; Kavalukas, S.L. Schwartz's Manual of Surgery, 8th ed.; McGraw-Hill Medical Pub. Division: New York, NY, USA, 2010.

50. Gurtner, G.C.; Werner, S.; Barrandon, Y.; Longaker, M.T. Wound repair and regeneration. Nature 2008, 453, 314-321. [CrossRef] [PubMed]

51. Valluru, M.; Staton, C.A.; Reed, M.W.; Brown, N.J. Transforming growth factor-beta and endoglin signaling orchestrate wound healing. Front. Physiol. 2011, 2, 89. [CrossRef] [PubMed]

52. Meyer, A.; Wang, W.; Qu, J.; Croft, L.; Degen, J.L.; Coller, B.S.; Ahamed, J. Platelet tgf-beta1 contributions to plasma tgf-beta1, cardiac fibrosis, and systolic dysfunction in a mouse model of pressure overload. Blood 2012, 119, 1064-1074. [CrossRef] [PubMed]

53. Assoian, R.K.; Komoriya, A.; Meyers, C.A.; Miller, D.M.; Sporn, M.B. Transforming growth factor-beta in human platelets. Identification of a major storage site, purification, and characterization. J. Biol. Chem. 1983, 258, 7155-7160. [PubMed]

54. Grainger, D.J.; Mosedale, D.E.; Metcalfe, J.C. Tgf-beta in blood: A complex problem. Cytokine Growth Factor Rev. 2000, 11, 133-145. [CrossRef] 
55. Brandes, M.E.; Mai, U.E.; Ohura, K.; Wahl, S.M. Type I transforming growth factor-beta receptors on neutrophils mediate chemotaxis to transforming growth factor-beta. J. Immunol. 1991, 147, 1600-1606. [PubMed]

56. Li, M.O.; Wan, Y.Y.; Sanjabi, S.; Robertson, A.K.; Flavell, R.A. Transforming growth factor-beta regulation of immune responses. Annu. Rev. Immunol. 2006, 24, 99-146. [CrossRef] [PubMed]

57. Reibman, J.; Meixler, S.; Lee, T.C.; Gold, L.I.; Cronstein, B.N.; Haines, K.A.; Kolasinski, S.L.; Weissmann, G. Transforming growth factor beta 1, a potent chemoattractant for human neutrophils, bypasses classic signal-transduction pathways. Proc. Natl. Acad. Sci. USA 1991, 88, 6805-6809. [CrossRef] [PubMed]

58. Mahdavian Delavary, B.; van der Veer, W.M.; van Egmond, M.; Niessen, F.B.; Beelen, R.H. Macrophages in skin injury and repair. Immunobiology 2011, 216, 753-762. [CrossRef] [PubMed]

59. Wahl, S.M.; Hunt, D.A.; Wakefield, L.M.; McCartney-Francis, N.; Wahl, L.M.; Roberts, A.B.; Sporn, M.B. Transforming growth factor type beta induces monocyte chemotaxis and growth factor production. Proc. Natl. Acad. Sci. USA 1987, 84, 5788-5792. [CrossRef] [PubMed]

60. Wiseman, D.M.; Polverini, P.J.; Kamp, D.W.; Leibovich, S.J. Transforming growth factor-beta (tgf beta) is chemotactic for human monocytes and induces their expression of angiogenic activity. Biochem. Biophys. Res. Commun. 1988, 157, 793-800. [CrossRef]

61. Chen, C.C.; Manning, A.M. Tgf-beta 1, IL-10 and IL-4 differentially modulate the cytokine-induced expression of IL-6 and IL-8 in human endothelial cells. Cytokine 1996, 8, 58-65. [CrossRef] [PubMed]

62. Heng, M.C. Wound healing in adult skin: Aiming for perfect regeneration. Int. J. Dermatol. 2011, 50, 1058-1066. [CrossRef] [PubMed]

63. Pastar, I.; Stojadinovic, O.; Yin, N.C.; Ramirez, H.; Nusbaum, A.G.; Sawaya, A.; Patel, S.B.; Khalid, L.; Isseroff, R.R.; Tomic-Canic, M. Epithelialization in wound healing: A comprehensive review. Adv. Wound Care 2014, 3, 445-464. [CrossRef] [PubMed]

64. Werner, S.; Grose, R. Regulation of wound healing by growth factors and cytokines. Physiol. Rev. 2003, 83, 835-870. [PubMed]

65. Guasch, G.; Schober, M.; Pasolli, H.A.; Conn, E.B.; Polak, L.; Fuchs, E. Loss of tgfb signaling destabilizes homeostasis and promotes squamous cell carcinomas in stratified epithelia. Cancer Cell 2007, 12, 313-327. [CrossRef] [PubMed]

66. Pietenpol, J.A.; Holt, J.T.; Stein, R.W.; Moses, H.L. Transforming growth factor beta 1 suppression of c-myc gene transcription: Role in inhibition of keratinocyte proliferation. Proc. Natl. Acad. Sci. USA 1990, 87, 3758-3762. [CrossRef] [PubMed]

67. Ramirez, H.; Patel, S.B.; Pastar, I. The role of tgfb signaling in wound epithelialization. Adv. Wound Care 2014, 3, 482-491. [CrossRef] [PubMed]

68. Wu, L.; Siddiqui, A.; Morris, D.E.; Cox, D.A.; Roth, S.I.; Mustoe, T.A. Transforming growth factor beta 3 (tgf beta 3 ) accelerates wound healing without alteration of scar prominence. Histologic and competitive reverse-transcription-polymerase chain reaction studies. Arch. Surg. 1997, 132, 753-760. [CrossRef] [PubMed]

69. Le, M.; Naridze, R.; Morrison, J.; Biggs, L.C.; Rhea, L.; Schutte, B.C.; Kaartinen, V.; Dunnwald, M. Transforming growth factor beta 3 is required for excisional wound repair in vivo. PLoS ONE 2012, 7, e48040. [CrossRef] [PubMed]

70. Lu, L.; Saulis, A.S.; Liu, W.R.; Roy, N.K.; Chao, J.D.; Ledbetter, S.; Mustoe, T.A. The temporal effects of anti-tgf-beta1, 2, and 3 monoclonal antibody on wound healing and hypertrophic scar formation. J. Am. Coll. Surg. 2005, 201, 391-397. [CrossRef] [PubMed]

71. Mustoe, T.A.; Pierce, G.F.; Thomason, A.; Gramates, P.; Sporn, M.B.; Deuel, T.F. Accelerated healing of incisional wounds in rats induced by transforming growth factor-beta. Science 1987, 237, 1333-1336. [CrossRef] [PubMed]

72. Puolakkainen, P.A.; Reed, M.J.; Gombotz, W.R.; Twardzik, D.R.; Abrass, I.B.; Sage, H.E. Acceleration of wound healing in aged rats by topical application of transforming growth factor-beta(1). Wound Repair Regen. 1995, 3, 330-339. [CrossRef] [PubMed]

73. Moustakas, A.; Heldin, C.H. Induction of epithelial-mesenchymal transition by transforming growth factor beta. Semin. Cancer Biol. 2012, 22, 446-454. [CrossRef] [PubMed] 
74. Nicolas, F.J.; Lehmann, K.; Warne, P.H.; Hill, C.S.; Downward, J. Epithelial to mesenchymal transition in madin-darby canine kidney cells is accompanied by down-regulation of smad3 expression, leading to resistance to transforming growth factor-beta-induced growth arrest. J. Biol. Chem. 2003, 278, 3251-3256. [CrossRef] [PubMed]

75. Ashcroft, G.S.; Yang, X.; Glick, A.B.; Weinstein, M.; Letterio, J.L.; Mizel, D.E.; Anzano, M.; Greenwell-Wild, T.; Wahl, S.M.; Deng, C.; et al. Mice lacking smad3 show accelerated wound healing and an impaired local inflammatory response. Nat. Cell Biol. 1999, 1, 260-266. [PubMed]

76. Jinno, K.; Takahashi, T.; Tsuchida, K.; Tanaka, E.; Moriyama, K. Acceleration of palatal wound healing in smad3-deficient mice. J. Dent. Res. 2009, 88, 757-761. [CrossRef] [PubMed]

77. Varelas, X.; Samavarchi-Tehrani, P.; Narimatsu, M.; Weiss, A.; Cockburn, K.; Larsen, B.G.; Rossant, J.; Wrana, J.L. The crumbs complex couples cell density sensing to hippo-dependent control of the tgf-beta-smad pathway. Dev. Cell 2010, 19, 831-844. [CrossRef] [PubMed]

78. Elbediwy, A.; Vincent-Mistiaen, Z.I.; Spencer-Dene, B.; Stone, R.K.; Boeing, S.; Wculek, S.K.; Cordero, J.; Tan, E.H.; Ridgway, R.; Brunton, V.G.; et al. Integrin signalling regulates yap/taz to control skin homeostasis. Development 2016, 143, 1674-1687. [CrossRef] [PubMed]

79. Folkman, J.; D'Amore, P.A. Blood vessel formation: What is its molecular basis? Cell 1996, 87, $1153-1155$. [CrossRef]

80. Nissen, N.N.; Polverini, P.J.; Koch, A.E.; Volin, M.V.; Gamelli, R.L.; DiPietro, L.A. Vascular endothelial growth factor mediates angiogenic activity during the proliferative phase of wound healing. Am. J. Pathol. 1998, 152, 1445-1452. [PubMed]

81. Singer, A.J.; Clark, R.A. Cutaneous wound healing. N. Engl. J. Med. 1999, 341, 738-746. [PubMed]

82. Tonnesen, M.G.; Feng, X.; Clark, R.A. Angiogenesis in wound healing. J. Investig. Dermatol. Symp. Proc. 2000, 5, 40-46. [CrossRef] [PubMed]

83. Carmeliet, P.; Jain, R.K. Molecular mechanisms and clinical applications of angiogenesis. Nature 2011, 473, 298-307. [CrossRef] [PubMed]

84. Fang, S.; Pentinmikko, N.; Ilmonen, M.; Salven, P. Dual action of tgf-beta induces vascular growth in vivo through recruitment of angiogenic vegf-producing hematopoietic effector cells. Angiogenesis 2012, 15, 511-519. [CrossRef] [PubMed]

85. Nicolosi, P.A.; Tombetti, E.; Maugeri, N.; Rovere-Querini, P.; Brunelli, S.; Manfredi, A.A. Vascular remodelling and mesenchymal transition in systemic sclerosis. Stem Cells Int. 2016, 2016, 4636859. [CrossRef] [PubMed]

86. Piera-Velazquez, S.; Mendoza, F.A.; Jimenez, S.A. Endothelial to mesenchymal transition (endomt) in the pathogenesis of human fibrotic diseases. J. Clin. Med. 2016, 5. [CrossRef] [PubMed]

87. Welch-Reardon, K.M.; Ehsan, S.M.; Wang, K.; Wu, N.; Newman, A.C.; Romero-Lopez, M.; Fong, A.H.; George, S.C.; Edwards, R.A.; Hughes, C.C. Angiogenic sprouting is regulated by endothelial cell expression of slug. J. Cell Sci. 2014, 127, 2017-2028. [CrossRef] [PubMed]

88. Reinke, J.M.; Sorg, H. Wound repair and regeneration. Eur. Surg. Res. 2012, 49, 35-43. [CrossRef] [PubMed]

89. Opalenik, S.R.; Davidson, J.M. Fibroblast differentiation of bone marrow-derived cells during wound repair. FASEB J. 2005, 19, 1561-1563. [CrossRef] [PubMed]

90. Abe, R.; Donnelly, S.C.; Peng, T.; Bucala, R.; Metz, C.N. Peripheral blood fibrocytes: Differentiation pathway and migration to wound sites. J. Immunol. 2001, 166, 7556-7562. [CrossRef] [PubMed]

91. Hinz, B. Formation and function of the myofibroblast during tissue repair. J. Investig. Dermatol. 2007, 127, 526-537. [CrossRef] [PubMed]

92. Leask, A.; Abraham, D.J. Tgf-beta signaling and the fibrotic response. FASEB J. 2004, 18, 816-827. [CrossRef] [PubMed]

93. Chin, G.S.; Liu, W.; Peled, Z.; Lee, T.Y.; Steinbrech, D.S.; Hsu, M.; Longaker, M.T. Differential expression of transforming growth factor-beta receptors I and II and activation of smad 3 in keloid fibroblasts. Plastic Reconstr. Surg. 2001, 108, 423-429. [CrossRef]

94. Querfeld, C.; Eckes, B.; Huerkamp, C.; Krieg, T.; Sollberg, S. Expression of tgf-beta 1, -beta 2 and -beta 3 in localized and systemic scleroderma. J. Dermatol. Sci. 1999, 21, 13-22. [CrossRef]

95. Ferguson, M.W.; Duncan, J.; Bond, J.; Bush, J.; Durani, P.; So, K.; Taylor, L.; Chantrey, J.; Mason, T.; James, G.; et al. Prophylactic administration of avotermin for improvement of skin scarring: Three double-blind, placebo-controlled, phase I/II studies. Lancet 2009, 373, 1264-1274. [CrossRef] 
96. Shah, M.; Foreman, D.M.; Ferguson, M.W. Neutralisation of tgf-beta 1 and tgf-beta 2 or exogenous addition of tgf-beta 3 to cutaneous rat wounds reduces scarring. J. Cell Sci. 1995, 108(Pt. 3), 985-1002. [PubMed]

97. Murata, H.; Zhou, L.; Ochoa, S.; Hasan, A.; Badiavas, E.; Falanga, V. Tgf-beta3 stimulates and regulates collagen synthesis through tgf-beta1-dependent and independent mechanisms. J. Investig. Dermatol. 1997, 108, 258-262. [CrossRef] [PubMed]

98. Hinz, B.; Dugina, V.; Ballestrem, C.; Wehrle-Haller, B.; Chaponnier, C. Alpha-smooth muscle actin is crucial for focal adhesion maturation in myofibroblasts. Mol. Biol. Cell 2003, 14, 2508-2519. [CrossRef] [PubMed]

99. Serini, G.; Gabbiana, G. Modulation of alpha-smooth muscle actin expression in fibroblasts by transforming growth factor-beta isoforms: An in vivo and in vitro study. Wound Repair Regen. 1996, 4, 278-287. [CrossRef] [PubMed]

100. Corr, D.T.; Gallant-Behm, C.L.; Shrive, N.G.; Hart, D.A. Biomechanical behavior of scar tissue and uninjured skin in a porcine model. Wound Repair Regen. 2009, 17, 250-259. [CrossRef] [PubMed]

101. Seifert, A.W.; Kiama, S.G.; Seifert, M.G.; Goheen, J.R.; Palmer, T.M.; Maden, M. Skin shedding and tissue regeneration in african spiny mice (acomys). Nature 2012, 489, 561-565. [CrossRef] [PubMed]

102. Brant, J.O.; Lopez, M.C.; Baker, H.V.; Barbazuk, W.B.; Maden, M. A comparative analysis of gene expression profiles during skin regeneration in mus and acomys. PLOS ONE 2015, 10, e0142931. [CrossRef] [PubMed]

103. Cass, D.L.; Bullard, K.M.; Sylvester, K.G.; Yang, E.Y.; Longaker, M.T.; Adzick, N.S. Wound size and gestational age modulate scar formation in fetal wound repair. J. Pediatr. Surg. 1997, 32, 411-415. [CrossRef]

104. Rowlatt, U. Intrauterine wound healing in a 20 week human fetus. Virchows Archiv. A Pathol. Anat. Histol. 1979, 381, 353-361. [CrossRef]

105. Barrientos, S.; Stojadinovic, O.; Golinko, M.S.; Brem, H.; Tomic-Canic, M. Growth factors and cytokines in wound healing. Wound Repair Regen. 2008, 16, 585-601. [CrossRef] [PubMed]

106. Soo, C.; Hu, F.Y.; Zhang, X.; Wang, Y.; Beanes, S.R.; Lorenz, H.P.; Hedrick, M.H.; Mackool, R.J.; Plaas, A.; Kim, S.J.; et al. Differential expression of fibromodulin, a transforming growth factor-beta modulator, in fetal skin development and scarless repair. Am. J. Pathol. 2000, 157, 423-433. [CrossRef]

107. Sullivan, K.M.; Lorenz, H.P.; Meuli, M.; Lin, R.Y.; Adzick, N.S. A model of scarless human fetal wound repair is deficient in transforming growth factor beta. J. Pediatr. Surg. 1995, 30, 198-202. [CrossRef]

108. Tanaka, E.M.; Reddien, P.W. The cellular basis for animal regeneration. Dev. Cell 2011, 21, 172-185. [CrossRef] [PubMed]

109. Kragl, M.; Knapp, D.; Nacu, E.; Khattak, S.; Maden, M.; Epperlein, H.H.; Tanaka, E.M. Cells keep a memory of their tissue origin during axolotl limb regeneration. Nature 2009, 460, 60-65. [CrossRef] [PubMed]

110. Lehoczky, J.A.; Robert, B.; Tabin, C.J. Mouse digit tip regeneration is mediated by fate-restricted progenitor cells. Proc. Natl. Acad. Sci. USA 2011, 108, 20609-20614. [CrossRef] [PubMed]

111. Rinkevich, Y.; Lindau, P.; Ueno, H.; Longaker, M.T.; Weissman, I.L. Germ-layer and lineage-restricted stem/progenitors regenerate the mouse digit tip. Nature 2011, 476, 409-413. [CrossRef] [PubMed]

112. Stoick-Cooper, C.L.; Moon, R.T.; Weidinger, G. Advances in signaling in vertebrate regeneration as a prelude to regenerative medicine. Genes Dev. 2007, 21, 1292-1315. [CrossRef] [PubMed]

113. Christensen, R.N.; Tassava, R.A. Apical epithelial cap morphology and fibronectin gene expression in regenerating axolotl limbs. Dev. Dyn. 2000, 217, 216-224. [CrossRef]

114. Nacu, E.; Tanaka, E.M. Limb regeneration: A new development? Annu. Rev. Cell Dev. Biol. 2011, 27, 409-440. [CrossRef] [PubMed]

115. Globus, M.; Vethamany-Globus, S.; Lee, Y.C. Effect of apical epidermal cap on mitotic cycle and cartilage differentiation in regeneration blastemata in the newt, notophthalmus viridescens. Dev. Biol. 1980, 75, 358-372. [CrossRef]

116. Neufeld, D.A.; Day, F.A.; Settles, H.E. Stabilizing role of the basement membrane and dermal fibers during newt limb regeneration. Anat. Rec. 1996, 245, 122-127. [CrossRef]

117. Campbell, L.J.; Crews, C.M. Wound epidermis formation and function in urodele amphibian limb regeneration. Cell. Mol. Life Sci. 2008, 65, 73-79. [CrossRef] [PubMed]

118. Campbell, L.J.; Suarez-Castillo, E.C.; Ortiz-Zuazaga, H.; Knapp, D.; Tanaka, E.M.; Crews, C.M. Gene expression profile of the regeneration epithelium during axolotl limb regeneration. Dev. Dyn. 2011, 240, 1826-1840. [CrossRef] [PubMed] 
119. Monaghan, J.R.; Athippozhy, A.; Seifert, A.W.; Putta, S.; Stromberg, A.J.; Maden, M.; Gardiner, D.M.; Voss, S.R. Gene expression patterns specific to the regenerating limb of the mexican axolotl. Biol. Open 2012, 1, 937-948. [CrossRef] [PubMed]

120. Thornton, C.S. The effect of apical cap removal on limb regeneration in amblystoma larvae. J. Exp. Zool. 1957, 134, 357-381. [CrossRef] [PubMed]

121. Inman, G.J.; Nicolas, F.J.; Callahan, J.F.; Harling, J.D.; Gaster, L.M.; Reith, A.D.; Laping, N.J.; Hill, C.S. $\mathrm{Sb}-431542$ is a potent and specific inhibitor of transforming growth factor-beta superfamily type I activin receptor-like kinase (alk) receptors alk4, alk5, and alk7. Mol. Pharmacol. 2002, 62, 65-74. [CrossRef] [PubMed]

122. Levesque, M.; Gatien, S.; Finnson, K.; Desmeules, S.; Villiard, E.; Pilote, M.; Philip, A.; Roy, S. Transforming growth factor: Beta signaling is essential for limb regeneration in axolotls. PLoS ONE 2007, 2, e1227. [CrossRef] [PubMed]

123. Ho, D.M.; Whitman, M. Tgf-beta signaling is required for multiple processes during xenopus tail regeneration. Dev. Biol. 2008, 315, 203-216. [CrossRef] [PubMed]

124. Jazwinska, A.; Badakov, R.; Keating, M.T. Activin-betaa signaling is required for zebrafish fin regeneration. Curr. Biol. 2007, 17, 1390-1395. [CrossRef] [PubMed]

125. Chablais, F.; Veit, J.; Rainer, G.; Jazwinska, A. The zebrafish heart regenerates after cryoinjury-induced myocardial infarction. BMC Dev. Biol. 2011, 11, 21. [CrossRef] [PubMed]

126. Chablais, F.; Jazwinska, A. The regenerative capacity of the zebrafish heart is dependent on tgfb signaling. Development 2012, 139, 1921-1930. [CrossRef] [PubMed]

127. Gilbert, R.W.; Vickaryous, M.K.; Viloria-Petit, A.M. Characterization of tgfb signaling during tail regeneration in the leopard gecko (eublepharis macularius). Dev. Dyn. 2013, 242, 886-896. [CrossRef] [PubMed]

128. Clark, L.D.; Clark, R.K.; Heber-Katz, E. A new murine model for mammalian wound repair and regeneration. Clin. Immunol. Immunopathol. 1998, 88, 35-45. [CrossRef] [PubMed]

129. Heber-Katz, E. The regenerating mouse ear. Semin. Cell Dev. Biol. 1999, 10, 415-419. [CrossRef] [PubMed]

130. Kreft, B.; Yokoyama, H.; Naito, T.; Kelley, V.R. Dysregulated transforming growth factor-beta in neonatal and adult autoimmune mrl-lpr mice. J. Autoimmun. 1996, 9, 463-472. [CrossRef] [PubMed]

131. Kench, J.A.; Russell, D.M.; Fadok, V.A.; Young, S.K.; Worthen, G.S.; Jones-Carson, J.; Henson, J.E.; Henson, P.M.; Nemazee, D. Aberrant wound healing and tgf-beta production in the autoimmune-prone mrl/+ mouse. Clin. Immunol. 1999, 92, 300-310. [CrossRef] [PubMed]

132. Watson, M.L.; Rao, J.K.; Gilkeson, G.S.; Ruiz, P.; Eicher, E.M.; Pisetsky, D.S.; Matsuzawa, A.; Rochelle, J.M.; Seldin, M.F. Genetic analysis of mrl-lpr mice: Relationship of the fas apoptosis gene to disease manifestations and renal disease-modifying loci. J. Exp. Med. 1992, 176, 1645-1656. [CrossRef] [PubMed]

133. Tolba, R.H.; Schildberg, F.A.; Decker, D.; Abdullah, Z.; Buttner, R.; Minor, T.; von Ruecker, A. Mechanisms of improved wound healing in murphy roths large (mrl) mice after skin transplantation. Wound Repair Regen. 2010, 18, 662-670. [CrossRef] [PubMed]

134. Liu, J.; Johnson, K.; Li, J.; Piamonte, V.; Steffy, B.M.; Hsieh, M.H.; Ng, N.; Zhang, J.; Walker, J.R.; Ding, S.; et al. Regenerative phenotype in mice with a point mutation in transforming growth factor beta type I receptor (tgfbr1). Proc. Natl. Acad. Sci. USA 2011, 108, 14560-14565. [CrossRef] [PubMed]

135. Akhurst, R.J.; Hata, A. Targeting the tgfb signalling pathway in disease. Nat. Rev. Drug Discov. 2012, 11, 790-811. [CrossRef] [PubMed]

136. Hawinkels, L.J.; Ten Dijke, P. Exploring anti-tgf-beta therapies in cancer and fibrosis. Growth Factors 2011, 29, 140-152. [CrossRef] [PubMed]

137. Herbertz, S.; Sawyer, J.S.; Stauber, A.J.; Gueorguieva, I.; Driscoll, K.E.; Estrem, S.T.; Cleverly, A.L.; Desaiah, D.; Guba, S.C.; Benhadji, K.A.; et al. Clinical development of galunisertib (ly2157299 monohydrate), a small molecule inhibitor of transforming growth factor-beta signaling pathway. Drug Des. Dev. Ther. 2015, 9, 4479-4499.

138. Carlson, M.E.; Conboy, M.J.; Hsu, M.; Barchas, L.; Jeong, J.; Agrawal, A.; Mikels, A.J.; Agrawal, S.; Schaffer, D.V.; Conboy, I.M. Relative roles of tgf-beta1 and wnt in the systemic regulation and aging of satellite cell responses. Aging Cell 2009, 8, 676-689. [CrossRef] [PubMed]

139. Chen, W.P.; Liu, Y.H.; Ho, Y.J.; Wu, S.M. Pharmacological inhibition of tgfb receptor improves nkx2.5 cardiomyoblast-mediated regeneration. Cardiovasc. Res. 2015, 105, 44-54. [CrossRef] [PubMed]

140. Xiao, Y.Q.; Liu, K.; Shen, J.F.; Xu, G.T.; Ye, W. Sb-431542 inhibition of scar formation after filtration surgery and its potential mechanism. Investig. Ophthalmol. Vis. Sci. 2009, 50, 1698-1706. [CrossRef] [PubMed] 
141. Ludbrook, S.B.; Barry, S.T.; Delves, C.J.; Horgan, C.M. The integrin alphavbeta3 is a receptor for the latency-associated peptides of transforming growth factors beta1 and beta3. Biochem. J. 2003, 369, 311-318. [CrossRef] [PubMed]

142. Reed, N.I.; Jo, H.; Chen, C.; Tsujino, K.; Arnold, T.D.; DeGrado, W.F.; Sheppard, D. The alphavbeta1 integrin plays a critical in vivo role in tissue fibrosis. Sci. Transl. Med. 2015, 7, 288ra279. [CrossRef] [PubMed]

143. Lonning, S.; Mannick, J.; McPherson, J.M. Antibody targeting of tgf-beta in cancer patients. Curr. Pharm. Biotechnol. 2011, 12, 2176-2189. [CrossRef] [PubMed]

144. Mead, A.L.; Wong, T.T.; Cordeiro, M.F.; Anderson, I.K.; Khaw, P.T. Evaluation of anti-tgf-beta2 antibody as a new postoperative anti-scarring agent in glaucoma surgery. Investig. Ophthalmol. Vis. Sci. 2003, 44, 3394-3401. [CrossRef]

145. Siriwardena, D.; Khaw, P.T.; King, A.J.; Donaldson, M.L.; Overton, B.M.; Migdal, C.; Cordeiro, M.F. Human antitransforming growth factor beta(2) monoclonal antibody-a new modulator of wound healing in trabeculectomy: A randomized placebo controlled clinical study. Ophthalmology 2002, 109, 427-431. [CrossRef]

146. Khaw, P.; Grehn, F.; Hollo, G.; Overton, B.; Wilson, R.; Vogel, R.; Smith, Z. A phase III study of subconjunctival human anti-transforming growth factor beta(2) monoclonal antibody (cat-152) to prevent scarring after first-time trabeculectomy. Ophthalmology 2007, 114, 1822-1830. [PubMed]

147. Bonafoux, D.; Lee, W.C. Strategies for tgf-beta modulation: A review of recent patents. Expert Opin. Ther. Pat. 2009, 19, 1759-1769. [CrossRef] [PubMed]

148. Ezquerro, I.J.; Lasarte, J.J.; Dotor, J.; Castilla-Cortazar, I.; Bustos, M.; Penuelas, I.; Blanco, G.; Rodriguez, C.; Lechuga Mdel, C.; Greenwel, P.; et al. A synthetic peptide from transforming growth factor beta type III receptor inhibits liver fibrogenesis in rats with carbon tetrachloride liver injury. Cytokine 2003, 22, 12-20. [CrossRef]

149. Santiago, B.; Gutierrez-Canas, I.; Dotor, J.; Palao, G.; Lasarte, J.J.; Ruiz, J.; Prieto, J.; Borras-Cuesta, F.; Pablos, J.L. Topical application of a peptide inhibitor of transforming growth factor-beta1 ameliorates bleomycin-induced skin fibrosis. J. Investig. Dermatol. 2005, 125, 450-455. [CrossRef] [PubMed]

150. Qiu, S.S.; Dotor, J.; Hontanilla, B. Effect of p144(r) (anti-tgf-beta) in an "in vivo" human hypertrophic scar model in nude mice. PLoS ONE 2015, 10, e0144489. [CrossRef] [PubMed]

151. Cordeiro, M.F.; Mead, A.; Ali, R.R.; Alexander, R.A.; Murray, S.; Chen, C.; York-Defalco, C.; Dean, N.M.; Schultz, G.S.; Khaw, P.T. Novel antisense oligonucleotides targeting tgf-beta inhibit in vivo scarring and improve surgical outcome. Gene Ther. 2003, 10, 59-71. [CrossRef] [PubMed]

152. Loiselle, A.E.; Yukata, K.; Geary, M.B.; Kondabolu, S.; Shi, S.; Jonason, J.H.; Awad, H.A.; O’Keefe, R.J. Development of antisense oligonucleotide (aso) technology against tgf-beta signaling to prevent scarring during flexor tendon repair. J. Orthop. Res. 2015, 33, 859-866. [CrossRef] [PubMed]

153. Thangapazham, R.L.; Sharad, S.; Maheshwari, R.K. Skin regenerative potentials of curcumin. BioFactors 2013, 39, 141-149. [CrossRef] [PubMed]

154. Jarvinen, T.A.; Ruoslahti, E. Targeted antiscarring therapy for tissue injuries. Adv. Wound Care 2013, 2, 50-54. [CrossRef] [PubMed]

155. Pines, M.; Spector, I. Halofuginone-The multifaceted molecule. Molecules 2015, 20, 573-594. [CrossRef] [PubMed]

156. Lichtman, M.K.; Otero-Vinas, M.; Falanga, V. Transforming growth factor beta (tgf-beta) isoforms in wound healing and fibrosis. Wound Repair Regen. 2016, 24, 215-222. [CrossRef] [PubMed]

157. Loeys, B.L. Angiotensin receptor blockers: A panacea for marfan syndrome and related disorders? Drug Discov. Today 2015, 20, 262-266. [CrossRef] [PubMed]

158. Cohn, R.D.; van Erp, C.; Habashi, J.P.; Soleimani, A.A.; Klein, E.C.; Lisi, M.T.; Gamradt, M.; ap Rhys, C.M.; Holm, T.M.; Loeys, B.L.; et al. Angiotensin II type 1 receptor blockade attenuates tgf-beta-induced failure of muscle regeneration in multiple myopathic states. Nat. Med. 2007, 13, 204-210. [CrossRef] [PubMed]

159. Kobayashi, T.; Uehara, K.; Ota, S.; Tobita, K.; Ambrosio, F.; Cummins, J.H.; Terada, S.; Fu, F.H.; Huard, J. The timing of administration of a clinically relevant dose of losartan influences the healing process after contusion induced muscle injury. J. Appl. Physiol. 2013, 114, 262-273. [CrossRef] [PubMed]

160. Kamber, M.; Papalazarou, V.; Rouni, G.; Papageorgopoulou, E.; Papalois, A.; Kostourou, V. Angiotensin II inhibitor facilitates epidermal wound regeneration in diabetic mice. Front. Physiol. 2015, 6, 170. [CrossRef] [PubMed] 
161. Schaefer, C.J.; Ruhrmund, D.W.; Pan, L.; Seiwert, S.D.; Kossen, K. Antifibrotic activities of pirfenidone in animal models. Eur. Respir. Rev. 2011, 20, 85-97. [CrossRef] [PubMed]

162. Ahluwalia, N.; Shea, B.S.; Tager, A.M. New therapeutic targets in idiopathic pulmonary fibrosis. Aiming to rein in runaway wound-healing responses. Am. J. Respir. Crit. Care Med. 2014, 190, 867-878. [CrossRef] [PubMed]

163. Chowdhury, S.; Guha, R.; Trivedi, R.; Kompella, U.B.; Konar, A.; Hazra, S. Pirfenidone nanoparticles improve corneal wound healing and prevent scarring following alkali burn. PLoS ONE 2013, 8, e70528. [CrossRef] [PubMed]

164. Mandapalli, P.K.; Labala, S.; Bojja, J.; Venuganti, V.V. Effect of pirfenidone delivered using layer-by-layer thin film on excisional wound healing. Eur. J. Pharm. Sci. 2016, 83, 166-174. [CrossRef] [PubMed]

165. Occleston, N.L.; O’Kane, S.; Laverty, H.G.; Cooper, M.; Fairlamb, D.; Mason, T.; Bush, J.A.; Ferguson, M.W. Discovery and development of avotermin (recombinant human transforming growth factor beta 3): A new class of prophylactic therapeutic for the improvement of scarring. Wound Repair Regen. 2011, 19, s38-s48. [CrossRef] [PubMed]

166. Bush, J.; Duncan, J.A.; Bond, J.S.; Durani, P.; So, K.; Mason, T.; O’Kane, S.; Ferguson, M.W. Scar-improving efficacy of avotermin administered into the wound margins of skin incisions as evaluated by a randomized, double-blind, placebo-controlled, phase ii clinical trial. Plastic Reconstr. Surg. 2010, 126, 1604-1615. [CrossRef] [PubMed]

167. McCollum, P.T.; Bush, J.A.; James, G.; Mason, T.; O’Kane, S.; McCollum, C.; Krievins, D.; Shiralkar, S.; Ferguson, M.W. Randomized phase ii clinical trial of avotermin versus placebo for scar improvement. Br. J. Surg. 2011, 98, 925-934. [CrossRef] [PubMed]

168. So, K.; McGrouther, D.A.; Bush, J.A.; Durani, P.; Taylor, L.; Skotny, G.; Mason, T.; Metcalfe, A.; O’Kane, S.; Ferguson, M.W. Avotermin for scar improvement following scar revision surgery: A randomized, double-blind, within-patient, placebo-controlled, phase ii clinical trial. Plastic Reconstr. Surg. 2011, 128, 163-172. [CrossRef] [PubMed]

169. Tang, Q.O.; Shakib, K.; Heliotis, M.; Tsiridis, E.; Mantalaris, A.; Ripamonti, U.; Tsiridis, E. Tgf-beta3: A potential biological therapy for enhancing chondrogenesis. Expert Opin. Biol. Ther. 2009, 9, 689-701. [CrossRef] [PubMed]

170. Almeida, H.V.; Liu, Y.; Cunniffe, G.M.; Mulhall, K.J.; Matsiko, A.; Buckley, C.T.; O’Brien, F.J.; Kelly, D.J. Controlled release of transforming growth factor-beta3 from cartilage-extra-cellular-matrix-derived scaffolds to promote chondrogenesis of human-joint-tissue-derived stem cells. Acta Biomater. 2014, 10, 4400-4409. [CrossRef] [PubMed]

171. Shakir, S.; MacIsaac, Z.M.; Naran, S.; Smith, D.M.; Bykowski, M.R.; Cray, J.J.; Craft, T.K.; Wang, D.; Weiss, L.; Campbell, P.G.; et al. Transforming growth factor beta 1 augments calvarial defect healing and promotes suture regeneration. Tissue Eng. Part A 2015, 21, 939-947. [CrossRef] [PubMed]

(C) 2016 by the authors; licensee MDPI, Basel, Switzerland. This article is an open access article distributed under the terms and conditions of the Creative Commons Attribution (CC-BY) license (http://creativecommons.org/licenses/by/4.0/). 